\title{
Science Learning in Elementary School with Project Based Learning Model
}

\author{
Esti Untari \\ Elementary School Teacher Education \\ Universitas Negeri Malang \\ Malang, Indonesia \\ esti.untari.fip@um.ac.id
}

\begin{abstract}
Science learning in elementary schools requires inspiring activities and emphasizes that students are active in the classroom. The project-based learning model is a studentcentered model to conduct an in-depth investigation of a topic. Project-based learning has characteristics that differ from other models, including 1) centrality, 2) driving question, 3) constructive investigation; 4) autonomy, and 5) realism. The stages in the model can make students active in learning so that this model is appropriate for use in natural science learning in elementary schools.
\end{abstract}

\section{Keywords - learning, science, project-based learning}

\section{INTRODUCTION}

The 2013 curriculum is a curriculum that enhances the existing curriculum. In the 2013 curriculum for SD / MI levels, the learning process implements integrated thematic learning. The characteristics of this learning center on students by providing direct experience, being flexible, and learning outcomes can develop in accordance with the interests and needs of students. Integrated thematic learning has the nature of guiding students to achieve higher levels of thinking or thinking skills by optimizing multiple thinking skills.

In Permendikbud No.103 of 2014 concerning learning in basic education and secondary education, learning is carried out based on activities with the characteristics of a) interactive and inspirational; b) fun, challenge and motivate students; c) Contextual and collaborative; d) provide sufficient space for the initiative, creativity and independence of students; and in accordance with the talents, interests, abilities and physical and psychological development of students. The learning approach in implementing the 2013 curriculum uses several learning strategies and models that have names, characteristics, syntax, settings, and culture, such as discovery learning, project-based learning, problem-based learning, inquiry learning.

Science in elementary schools is identical with boring subjects and the amount of material that needs to be memorized, besides that teachers are still less than optimal in using models that are appropriate to the characteristics of science. In fact, teachers often use conventional methods in learning activities. One of the learning models recommended in implementing the 2013 curriculum is the project-based learning model. This learning fosters student activity and provides knowledge with meaningful learning.

\author{
Sukamti \\ Elementary School Teacher Education \\ Universitas Negeri Malang \\ Malang, Indonesia \\ kamti.pgsd@gmail.com
}

\section{SCIENCE LEARNING IN ELEMENTARY SCHOOL}

Natural Science (IPA) the study of nature systematically, so that IPA is not only mastering a collection of knowledge in the form of facts, concepts, or principles, but also a process of discovery. Science Education is directed to find out and do so that it can help students to help a deeper understanding of the natural surroundings. According to Ratna Wilis Dahar [1] Irianto, M. D and Syaluudin, D., 1999: 8 "If we only teach science in the form of facts, concepts, principles, theories, to students without them knowing and having a scientific process, then what we teach not science." Science is defined as having three important elements, namely attitude, process, and product. Therefore, students must be motivated to be actively involved in the scientific work processes carried out in each lesson.

The goal of science learning is that students have three basic science abilities, namely: (1) the ability to know what is observed, (2) the ability to predict what has not happened, and the ability to test the follow-up of experimental results, (3) the development of a scientific attitude.

Learning science should be carried out in scientific inquiry (scientific inquiry) to foster the ability to think, work and be scientific and communicate it as an important aspect of life skills. Therefore, science learning in elementary schools emphasizes the provision of direct learning experiences through the use and development of process skills and scientific attitudes. Learning activities carried out in elementary school lead students to interact directly with the surrounding environment to form concepts and recognize the surrounding objects in a concrete manner.

\section{PROJECT BASEd LEARNING Model}

Project-based learning is a learning model that uses problems as a first step in collecting and integrating new knowledge based on their experiences in real activities. Project-based learning is a student-centered learning model to conduct an in-depth investigation of a topic. Students constructively explore learning with a research-based approach to problems and questions that are weighted, real and relevant [2].

According to Cord et al. project-based learning is an innovative learning model or approach, which emphasizes contextual learning through complex activities [3]. Projectbased learning is the use of a project as a learning model. Projects put students in an active role, namely as problem solvers, decision makers, researchers, and document makers 
Project-based learning comes from John Dewey's idea of the concept of "Learning by Doing" namely the process of obtaining learning outcomes by doing certain actions in accordance with its objectives, especially the mastery of children about how to do something work which consists of a series of behaviors to achieve a goal [4]. Problem-based learning and project-based learning are very similar, both of which emphasize active student learning environments, collaborative work, and authentic assessment techniques. So in project-based learning students are more encouraged in design activities: formulating jobs, designing (designing), calculating, carrying out work and evaluating results [5]. Based on the opinion of some experts above that projectbased learning is learning, a learning model that makes students more active in learning activities by doing problemsolving activities provided by the teacher, and solving problems using scientific methods.

\section{Characteristics of Project-BASEd Learning}

Project-based learning has characteristics according to the Center for Youth Development and Education-Boston [6], namely: 1) involving students in complex problems, problems in the real world, wherever students can choose and determine problems or problems that are meaningful to them; 2) students are required to use investigations, research planning skills, critical thinking and problem-solving skills when they complete the project; 3) students are required to learn and apply the skills and knowledge they have in various contexts when working on projects; 4) provide opportunities for students to learn and practice personal skills when they work in cooperative teams, as well as when discussing with teachers; 5) giving students the opportunity to practice the various skills needed for their adult life and career (how to allocate time, become responsible individuals, personal skills, learning through experience); 6) convey expectations regarding achievement / learning outcomes; this is adapted to the standards and learning objectives for schools/countries; 7) do reflections that direct students to think critically about their experiences and relate experiences with lessons; 8) ends with a presentation or product that shows learning and is then assessed, criteria can be determined by students.

Project-based learning has characteristics that differ from other models, including 1) Centrality, being the center of learning; 2) Driving question, focused on questions or problems that lead students to find solutions with appropriate concepts or principles of science; 3) Constructive Investigation, students build their knowledge by independently investigating (teachers as facilitators); 4) Autonomy, demanding student-centered, students as a problem solver of the problems discussed; 5) Realism, student activities are focused on work that is similar to the actual situation. These activities integrate authentic tasks and produce professional attitudes [7].

\section{Stage of Project-Based Learning Learning}

The traditional learning process is different from projectbased learning, encouraging students to issue ideas to solve complex problems taken from real life so that the stages of learning between the two are not the same. Project-based learning steps are carried out in 3 stages [8], namely:

\section{A. Stage of Project Planning}

Planning steps are as follows: a. formulate learning objectives to be achieved; b. determine the topics to be discussed; c. grouping students into small groups of 4-5 people with varying abilities; d. design and compile LKS; e. designing learning resource needs; f establish an assessment plan.

\section{B. Implementation Phase}

Students in each group carry out the project by investigating or thinking with their abilities based on their experience. Then a group discussion was held. While the teacher guides students who experience difficulties by acting as facilitators.

\section{Assessment Stage}

At this stage, the teacher evaluates the work of each group. Based on this assessment, the teacher can draw conclusions on whether the activity needs to be improved or not, and which parts need to be improved.

\section{Project Based Learning Learning StePS}

Project-based learning steps (syntax) as developed by [9]the George Lucas Educational Foundation 2005:

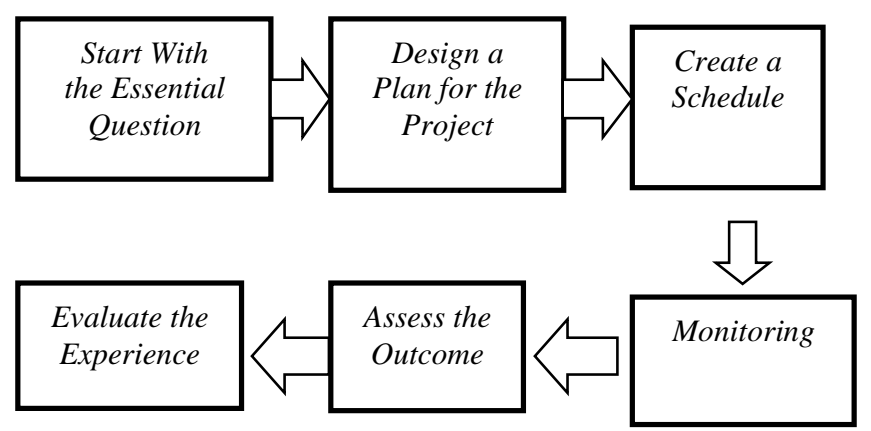

Fig. 1. Project-based learning steps (syntax)

\section{A. Determination of Fundamental Questions (Start With The Essential Question)}

The first step is to stimulate students to make questions. The investigation carried out starting from the question and adjusted to the circumstances of the surrounding environment.

\section{B. Designing Project Planning (Design A Plan For The Project)}

Teachers and students plan collaboratively. So that students are expected to "own" the project. In planning contains the rules in completing the project, the selection of activities that support in answering the essential questions, by integrating various possible subjects, and knowing the tools and materials that can be used to assist in the completion of the project.

\section{Arrange A Schedule (Create A Schedule)}

Teachers and students collectively schedule activities in completing the project. Activity activities at this stage include: creating an implementation schedule of activities to complete the project, determining the final deadline for project completion. Besides that invites students to plan new 
ways, guide students when they make ways that are not related to the project, and ask students to make an explanation (reason) about choosing a method.

\section{Monitor Students And Project Progress (Monitor The Students and The Progress Of The Project)}

Teachers and students collectively schedule activities in completing the project. Activity activities at this stage include: creating an implementation schedule of activities to complete the project, determining the final deadline for project completion. Besides that invites students to plan new ways, guide students when they make ways that are not related to the project, and ask students to make an explanation (reason) about choosing a method.

\section{E. Assessing the Outcome Assessment}

Evaluation is done to find out the understanding and measure the achievement of standards and the role of each student in learning. This activity helps the teacher in making plans for the next learning.

\section{F. Evaluating the Experience (Evaluate the Experience)}

This stage is carried out to reflect all learning activities about students' responses to learning activities and the results of projects that have been carried out. This activity is carried out both individually, in groups and as a whole class to find out the experiences of students during the learning process that has been done.

\section{AdVANTAgeS OF PROJECT-BASED LEARNING ModELS}

In each learning model has its own advantages, there is no perfect model for all learning to be applied. However, there are several advantages to each method. The advantages of using project-based learning according to Khamdi [6] are as follows:

- Increase motivation. Written reports on many projects say that students are diligent until the deadline, trying hard to achieve the project.

- Improve problem-solving skills. Activities in this model can improve high-level cognitive skills and students can be directly involved in solving existing problems. The learning environment in this learning can make students become active and able to solve problems in the environment.

- Increase collaboration. In a group work can develop and improve students' communication skills in groups. The aspect of collaboration is seen in the work group, evaluation and information exchange when problems occur in project work carried out.

- Improve resource management skills. This learning provides students with the skills to search for resources and manage them in problem solving. So that students can be responsible for the sources used in solving problems.

According to Moursund in Made Wena's book, the advantages of project-based learning include the following:

- Increased motivation. Project-based learning can improve student learning motivation as evidenced by several research reports on project-based learning stating that students are very diligent, trying to complete projects, students feel more passionate about learning, and delays in attendance are greatly reduced.

- Increased Problem-solving ability, some sources describe that the learning environment of projectbased learning can improve problem-solving skills, make students more active, and successfully solve complex problems.

- Improved library research skills. Because projectbased learning requires students to be able to quickly be able to obtain information through information sources, the students' skills to seek and obtain information will increase.

- Increased collaboration. The importance of group work in projects requires students to develop and practice communication skills. Cooperative work groups, student evaluation, online information exchange are collaborative aspects of the project.

- Increased resource-management skills. Project-based learning that is implemented well gives students learning and tactics in organizing projects and making allocations of time and other resources such as equipment to complete tasks.

\section{VIII.LEARNING THEORY RELATED TO THE PROJECT BASED LEARNING MODEL}

Project-based learning model is based on constructivist learning theory. The learning process occurs, among others, includes setting up the stimulus that is received and adjusting it to the cognitive structure that is already owned and formed in the mind. Piaget's opinion about cognitive development is stated in [10] Margaret E. Bell Gredler, as follows: "Cognitive development is influenced by three basic processes, namely assimilation, accommodation, and equilibration. Briefly, assimilation is the integration of new data with cognitive structures that there is, accommodation is the adjustment of the cognitive structure to the emotional situation and the calibration is a continual readjustment between assimilation and accommodation".

Piaget in Ratna Wilis Dahar [11], divides the process of cognitive development into several stages, where at each stage it has characteristics and is adjusted to its age. In each individual there is a level of intellectual development, as follows: a) motor sensory (0-2 years), b) pre-operational (2-7 years), c) concrete operations (7-11 years), d) formal operations (11 years and over)."

Vygotsky's theory is now recognized as one of the important theories in developmental psychology. An important contribution of Vygotsky's theory is the emphasis on the socio-cultural nature of learning. Vygotsky further believes that learning occurs when the child works or learns to handle tasks that have not been studied but the task is still within its ability or the tasks are in the Zone of Proximal Development (ZPD). The development of a little above the level of one's current development, among others, is the level of preliminary knowledge or basic knowledge that has been mastered. Based on the theory, interactive learning is developed, namely, students are easier to find and understand concepts that are difficult if they discuss each other's problems with their friends. 
Theory of learning is stated by Bruner in Arends [12]. Learning is about three processes that take place almost simultaneously, namely: a) obtaining new information, b) transformation of knowledge, c) testing the relevance and accuracy of knowledge, this learning is called discovery learning. So students will get their knowledge in accordance with the search for knowledge active, by itself giving the best results. Bruner's opinion about learning is very compatible with one of the advantages of problem-based learning, namely students will gain meaningful knowledge.

In learning students try themselves to find problemsolving and the accompanying knowledge, if the problem has been separated, it produces knowledge that is truly meaningful. In this problem-based learning, students perform tasks in the form of projects by doing learning by discovery. In accordance with Bruner's theory, that learning is an active process that allows humans to discover new things beyond the information given to them. So in problem-based learning in this study, elementary students will experience looking for problems through investigations and discoveries and how to solve them requires the existence of activities, maintenance, and direction. This means that learning activities will run well and creatively if students can find their own specific rules or conclusions. In other words, the child is guided in understanding something from the most specific (deductive) to the most complex (inductive), rather than the concept that was first taught, but concrete examples of honesty itself.

Problem-based learning has intellectual roots in the work of John Dewey. He produced the work of Democracy and Education (1916) in which he described the view of education with a school as a mirror of a larger society and class that became a laboratory for investigation and overcoming real-life problems. pedagogy John Dewey encourages teachers to engage students in various problemoriented projects and help them investigate important social and intellectual problems. Dewey in Arends, [12] said: "that learning in schools should have a clear purpose (Purposeful) which encourages students to conduct investigations with small groups according to their interests." Students carry out projects in groups (three people) and investigate according to their interests.

\section{RESEARCH WITH PROJECT BASED LEARNING ModELS}

Learning Project Based Learning models have been studied by several researchers. The following are the results of the relevant study analysis shows in Table 1.

TABLE I. STUDY ANALYSIS RELEVANT TO PROJECT-BASED LEARNING MODEL LEARNING

\begin{tabular}{|l|l|l|l|}
\hline \multicolumn{1}{|c|}{$\begin{array}{c}\text { Researcher \& } \\
\text { Year }\end{array}$} & Subject & \multicolumn{1}{|c|}{$\begin{array}{c}\text { Ability } \\
\text { Researched }\end{array}$} & \multicolumn{2}{|c|}{ Research Result } \\
\hline $\begin{array}{l}\text { [13] Amanatul } \\
\text { Munawaroh, } \\
\text { dkk (2013) }\end{array}$ & $\begin{array}{l}\text { Middle } \\
\text { school }\end{array}$ & $\begin{array}{l}\text { Student } \\
\text { activities } \\
\text { Student } \\
\text { learning } \\
\text { outcomes }\end{array}$ & $\begin{array}{l}\text { The application of } \\
\text { project-based } \\
\text { learning models } \\
\text { can improve } \\
\text { student learning } \\
\text { outcomes }\end{array}$ \\
\hline $\begin{array}{l}\text { [14] N. Yahya } \\
\text { (2014) }\end{array}$ & High school & $\begin{array}{l}\text { Student } \\
\text { activities, } \\
\text { student } \\
\text { creativity, } \\
\text { product } \\
\text { creativity }\end{array}$ & $\begin{array}{l}\text { Activities and } \\
\text { creativity } \\
\text { students with } \\
\text { project learning } \\
\text { models increase } \\
\text { and produce } \\
\text { products that }\end{array}$ \\
\hline
\end{tabular}

\begin{tabular}{|c|c|c|c|}
\hline $\begin{array}{c}\text { Researcher \& } \\
\text { Year }\end{array}$ & Subject & $\begin{array}{c}\text { Ability } \\
\text { Researched }\end{array}$ & Research Result \\
\hline & & & $\begin{array}{ll}\text { show } & \text { student } \\
\text { creativity } & \\
\end{array}$ \\
\hline 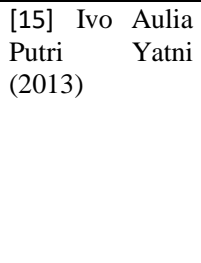 & $\begin{array}{l}\text { Elementary } \\
\text { school }\end{array}$ & $\begin{array}{l}\text { Student } \\
\text { learning } \\
\text { outcomes }\end{array}$ & $\begin{array}{l}\text { The application of } \\
\text { a project-based } \\
\text { learning model } \\
\text { can improve } \\
\text { students' abilities, } \\
\text { especially aspects } \\
\text { of knowledge and } \\
\text { skills }\end{array}$ \\
\hline $\begin{array}{l}\text { [16] Anike Suci } \\
\text { Badriawan } \\
(2014)\end{array}$ & $\begin{array}{l}\text { Vocational } \\
\text { High School }\end{array}$ & $\begin{array}{l}\text { Student } \\
\text { learning } \\
\text { activities }\end{array}$ & $\begin{array}{l}\text { Increased activity } \\
\text { with which can be } \\
\text { seen from the } \\
\text { increased activity } \\
\text { of students that } \\
\text { can be seen from } \\
\text { increased student } \\
\text { learning } \\
\text { activeness which } \\
\text { includes visual } \\
\text { activities, oral } \\
\text { activities, } \\
\text { listening } \\
\text { activities, writing } \\
\text { activities, motor } \\
\text { activities, mental } \\
\text { activities, } \\
\text { emotional } \\
\text { activities }\end{array}$ \\
\hline
\end{tabular}

Based on Table I., the project-based learning model that has been carried out at different levels shows an increase in student learning outcomes, student activities, and creativity. Besides this model makes students more active in learning Conclusions and Suggestions

\section{CONCLUSION}

In the 2013 curriculum for SD / MI levels, the learning process implements integrated thematic learning. Learning in elementary schools should have a purposeful purpose (Purposeful) to encourage students to conduct investigations with small groups according to their interests. Project-based learning has characteristics that differ from other models, including 1) Centrality; 2) Driving question; 3) Constructive Investigation; 4) Autonomy; 5) Realism. The stages in the model can make students active in learning so that this model is appropriate for learning in science. This model is highly recommended to be used in learning science in elementary schools because it can improve the activity and creativity of students in learning.

\section{REFERENCE}

[1] Irianto, M. D dan Syaluudin, D. 1999. "Handout Pembelajaran IPA Sekolah Dasar". Bandung:IKIP

[2] Grant, M.M. 2002. "Getting A Grip of Project Based Learning: Theory, Cases and Recomandation". North Carolina: Meredia A Middle School Computer Technologies. Journal Vol. 5

[3] Khamdi, W. 2007. "Pembelajaran berbasis Proyek: Model Potensi untuk meningkatkan Mutu Pembelajaran". http;//lubisgrafura.wordprees.com.

[4] Moeslichatoen, 2004. Metode Pengajaran di Taman Kanak -kanak. Jakarta: Rineka Cipta

[5] Wena, Made, Strategi Pembelajaran Inovatif Kontemporer suatu Tinjauan Konseptual Operasional, Jakarta : Bumi Aksara, 2010. 
[6] Muliawati. 2010. Penerapan Model Pembelajaran Project Based Learning untuk Meningkatkan Berfikir Kritis Siswa. Skripsi FPMIPA UPI. Bandung: Tidak diterbitkan.

[7] Thomas, J. W., 2000.A Review od Research on Project Based Learning. California: The Autodesk Foundation, Available on: http;//www.autodesk.com/foundation.

[8] Anita Lie. 2007. Kooperatif Learning (Mempraktikkan Cooperative Learning di. Ruang-ruang Kelas). Jakarta: Grasindo

[9] The George Lucas Educational Foundation. 2005. Instructional Module Project Based Learning. http//www.edutopia.org.modules/PBL/whatpbl.php.2005

[10] Gredler, Margaret E.Bell. 1991. Belajar dan Membelajarkan. Jakarta:Rajawali

[11] Dahar, Ratna Wilis. 1989. Teori - teori Belajar. Jakarta. Erlangga.

[12] Arends, Richard. 2007. Learning to Teach. Yogykarta: Pustaka Pelajar
[13] Amanatul Munawaroh \& Wulan Christijanti .2013. Penerapan Model Pembelajaran Berbasis Proyek Untuk Meningkatkan Hasil Belajar Sistem Pencernaan SMP. Unnes Journal of Biology Education. http://journal.unnes.ac.id/sju/index.php/ujeb

[14] Yahya, N. 2014. Model Pembelajaran Berbasis Proyek Berbantuan Media Kultur Jaringan Untuk Meningkatkan Aktivitas Dan Kreativitas Siswa Kelas XII IPA SMA Negeri 1 Bangsri. Jurnal Pendidikan IPA Indonesia. http://journal.unnes.ac.id/nju/index.php/jpii

[15] Ivo Aulia Putri Yatni. 2013. Implementasi Model Project Based Learning Untuk Meningkatkan Hasil Belajar Siswa Pada Materi Sumber Daya Alam. Perpustakaan.upi.edu.repository.upi.edu

[16] Anike Suci Badriawan. 2014. Penerapan Metode Proyek Guna Meningkatkan Keaktifan Siswa Dalam Pembelajaran Pendidikan Agama Islam di SMK Islam Ruhama, Tanggerang Selatan. Skripsi Uin Syarif Hidayatullah. Jakarta: Unpublished. 